\title{
Development of Organizational Care and Support Inventory for Sheltered Street Children
}

\author{
Dr. G. Sarvani ${ }^{1}$
}

\section{ABSTRACT}

The present study is aimed at developing organizational care and support inventory with six dimensions viz. physical facilities, Educational facilities, Health problems, Social support, Peer group support and Moral support. After consulting experts 55 items were selected. A purposive sample 444 sheltered street children (government 176, non government 268) was selected various shelters in Hyderabad and Vijayawada cities of Telagana and Andhra Pradesh. The items of organizational care and support inventory were tested into two steps. In the first step, the discriminative ability of each statement was examined by comparing the mean scores of the first and last quartiles on each statement. The second step of testing involved the computation of inter correlation among the variables. It was also observed that numbers of clusters are found in correlation matrix of organizational care and support determinants. Hence, it was decided that a factor analysis, using principle of component solutions and rotated to a varimax criterion (Kaiser 1958) with an Eigen value of 1 . After the factor analysis, 46 items are loaded into seven factors, remaining items are deleted and an inter correlation of the seven factors was performed.

Keywords: Organizational Care And Support, Street Children, Inter Correlation, Principle Of Component Method, Factor Analysis,

The need for love, as well as for security, is a powerful motivator of behavior (Brendtro et al., 1990). Alienated youths, experiencing harsh social conditions, may seek alternative ways to fulfill these needs, including running away. Young people also desire autonomy. For many street children, freedom from adult control is the most important attribute of their adopted way of life (Scharf et al., 1986). Street children who experience harsh social conditions and broken family relations tend to have behavioral problems. They seek alternative ways to fulfill their needs, by running away from their homes. Pringle (1974) grouped the psychosocial needs of children into four main areas: i) the need for love and security, ii) the need for new experiences, iii) the need for praise and recognition and iv) the need for responsibility. If these needs are not met or are thwarted, children may be at risk for emotional and behavioral problems, and fulfillment sought elsewhere (away from the family unit). Street children may fall into this category.

${ }^{1}$ Lecturer, Dept. of Psychology, Dr. L.B college of education

(C) 2015 I G Sarvani; licensee IJIP. This is an Open Access Research distributed under the terms of the Creative Commons Attribution License (http://creativecommons.org/licenses/by/2.0), which permits unrestricted use, distribution, and reproduction in any Medium, provided the original work is properly cited. 


\section{Development of Organizational Care and Support Inventory for Sheltered Street Children}

\section{Organizational care and support}

Once when the children leave their homes, psychologically they are pathetic, they need emotional support and they face many difficulties in street life. When they are enrolled in any organization, they expect some care, support and protection and usually they dislike too much security in shelters. Hence, the care and support provided by the organization and past experiences like familial and personal problems have a significant influence on the behavioral problems of street children. If the children receive proper care and support by organization, they feel happy, comfortable and become normal individuals.

Different organizations are rendering some kind of support to street children. The fact remains that a street child is "a child" who should be assisted by parents and the school in his process of becoming an adult. This crucial factor is at present often over looked by these organizations that render support. These support structures direct their attention to activities that often exclude the school and the family context which are crucial in the child's becoming. The actualization of the child's full potential therefore becomes more remote.

\section{Sample:}

The sample for the present study belongs to the lower socio economic status with similar background in family living style has been chosen. The sampling procedure adopted is more or less purposive. Out of the total 444 respondents, 176 are from government shelters, and 268 are from non-government shelters. All the 268 children covered from the non-government shelters are boys while 68 of the 176 children from government shelters are girls. The average mean age of the participants is about 17.

\section{Development of Measures for Organizational Care and Support:}

In the present study, different measures for organizational care and support were adopted basing on the following earlier research studies:

- Zena Amury and Aneth Komba (2010) developed structured interviewed questionnaire, all the items are related to health parameter.

- "My work Book", developed by Sekar from National Institute of Mental Health and Neuro science (NIMHANS). Needs: related to physical needs, schooling and peer group support.

- UNICEF and Arab league (2005) developed a questionnaire some items related to care provided by shelter homes to street children.

- Janse van Rensburg (1994) questionnaire related to physical needs, schooling, peer group support and moral support given by caretakers of shelter homes.

The view, experiences with formal and informal investigations, experiences by the above are taken into account as a source for constructing and designing the organizational care and support questionnaire. Some items are taken as it is; some items related to street life are modified in order to suit the situation. After modifications, the questionnaire was given to judges for examining its suitability and accuracy to use in the present investigation. All the judges 
unanimously agreed on its applicability. The items or aspects in the questionnaire are classified into six categories; viz., physical facilities, educational facilities, health problems, social support, peer group support and moral support. A total of 55 items were selected for their diversity in relevance to organizational care and support. Each item was represented as a single statement. Respondents were asked to rate each item on a five point liker scale - where a score of 'one' indicates strongly disagree and 'five' indicates strongly agree, with intermediary scores of undecided. Reverse scoring was given for some of the negative statements present in the questionnaire.

\section{Example:}

Physical facilities: we have sufficient clothing in our shelter.

5=strongly agree, 4=agree, 3= undecided, 4=disagree, 5=strongly disagree.

Health problems: I have hearing problems.

1=strongly agree, 2=agree, 3= undecided, 4=disagree, 5=strongly disagree.

The responses were scored in a manner such that a high score indicates more agreement towards the particular organizational care and support. The items of organizational care and support scale were tested into two steps. In the first step, the discriminative ability of each statement was examined by comparing the mean scores of the first and last quartiles on each statement. The results of this analysis are presented in table -1 . Since all the variables exhibit significant differences, they have been selected for the inclusion in the scale.

The second step of testing involved the computation of inter correlation among the variables. Such correlations are theoretically possible by virtue of their definitions. It was also observed that numbers of clusters are found in correlation matrix of organizational care and support determinants. Hence, it was decided that a factor analysis would resolve these issues more meaningfully.

The data were factor analyzed using principle component solutions and rotated to a varimax criterion (Kaiser 1958) with an Eigen value of 1 . The results of this analysis are presented in table - 2. After the factor analysis, 46 items are loaded into seven factors, remaining items are deleted. The seven -factor solution accounts 66.6 percent of the common variance. All the items loading more than 0.44 on a single item of the factor were included. A description of the seven factors is provided below.

Factor - I comprises of seven variables. These are sufficient clothing, basic facilities, clean water for drinking, enough food, sufficient place for sleep, clean and neat surroundings, sufficient bedding, play lots of games, sufficient play ground. The highest factor loading of 0.75 is for sufficient clothing and lowest of 0.44 is for playing lots of games. In view of the definitions of these variables, this factor was named as 
Development of Organizational Care and Support Inventory for Sheltered Street Children

TABLE -1

DISCRIMINATIVE ANALYSIS FOR PERCEIVING ORGANIZATIONAL CARE AND SUPPORT ITEMS BETWEEN FIRST AND LAST QUARTILES

\begin{tabular}{|c|c|c|c|c|c|c|}
\hline \multirow[t]{2}{*}{ S.NO } & \multirow[t]{2}{*}{$\begin{array}{l}\text { Perceiving care and support of organization } \\
\text { Items }\end{array}$} & \multicolumn{2}{|c|}{$\begin{array}{c}\text { First Quartile } \\
(n=25)\end{array}$} & \multicolumn{2}{|c|}{$\begin{array}{l}\text { Last Quartile } \\
(n=25)\end{array}$} & \multirow[t]{2}{*}{ t-value } \\
\hline & & Mean & S.D & Mean & S.D & \\
\hline 1 & Adequate place for sleep & 4.96 & 0.2 & 3.92 & 0.33 & $4.52^{* *}$ \\
\hline 2 & Individual bedding & 4.88 & 0.33 & 3.92 & 0.48 & $9.16^{* *}$ \\
\hline 3 & Enough food & 4.92 & 0.27 & 3.88 & 0.43 & $4.41^{* *}$ \\
\hline 4 & Adequate water to drink & 4.65 & 0.27 & 3.84 & 0.84 & $7.91^{* *}$ \\
\hline 5 & Sufficient clothes & 4.84 & 0.37 & 3.53 & 0.37 & $4.73^{\circ *}$ \\
\hline 6 & Adequate basic facilities & 4.80 & 0.40 & 3.65 & 0.79 & $5.19^{* *}$ \\
\hline 7 & Surroundings are neat and clean & 4.64 & 0.56 & 3.73 & 0.53 & $3.44^{* *}$ \\
\hline 8 & Frequently we move to sight seeing & 4.60 & 0.57 & 3.53 & 0.58 & $3.44^{* *}$ \\
\hline 9 & Playing games & 3.32 & 0.90 & 5.00 & 0.00 & $9.33^{* *}$ \\
\hline 10 & Adequate play ground & 4.84 & 0.37 & 3.11 & 0.71 & $2.86^{* *}$ \\
\hline 11 & Extracurricular activities & 4.16 & 1.14 & 2.57 & 0.90 & $8.08^{* *}$ \\
\hline 12 & Compulsory primary education & 4.60 & 0.70 & 4.15 & 0.53 & $7.02^{* *}$ \\
\hline 13 & Sufficient stationary & 4.80 & 0.40 & 3.92 & 0.62 & $3.46^{* *}$ \\
\hline 14 & I like school & 4.8 & 0.40 & 3.92 & 0.39 & $7.02^{* *}$ \\
\hline 15 & Sharing doubts with others & 4.72 & 0.84 & 4.00 & 0.48 & $2.28^{*}$ \\
\hline 16 & Teachers clarifies our doubts & 4.76 & 0.59 & 4.19 & 0.49 & $3.28^{* *}$ \\
\hline 17 & Teachers concerned about academics & 4.92 & 0.50 & 4.23 & 0.51 & $4.58^{* *}$ \\
\hline 18 & I like studies & 4.70 & 0.75 & 3.38 & 0.94 & $7.15^{* *}$ \\
\hline 19 & Training in computers/ mechanical & 4.76 & 0.66 & 3.26 & 1.34 & $7.92^{* *}$ \\
\hline 20 & Training in vocational courses & 4.72 & 0.54 & 3.53 & 0.90 & $8.63^{* *}$ \\
\hline 21 & Library facility & 4.56 & 0.96 & 3.96 & 0.66 & $5.28^{* *}$ \\
\hline 22 & Providing Job opportunities after education & 4.52 & 1.00 & 4.30 & 0.61 & $6.33^{*}$ \\
\hline 23 & Education with morals & 4.84 & 0.47 & 4.30 & 0.97 & $6.33^{\circ *}$ \\
\hline 24 & Guidance and counseling facility & 4.72 & 0.67 & 3.53 & 0.94 & $5.45^{* *}$ \\
\hline 25 & Emergency medical services & 4.72 & 0.54 & 3.96 & 0.44 & $7.45^{\circ *}$ \\
\hline 26 & Regular health check ups & 4.76 & 0.43 & 4.03 & 0.44 & $4.07^{* *}$ \\
\hline 27 & First aid facility & 3.36 & 1.04 & 230 & 1.04 & $2.85^{* *}$ \\
\hline 28 & Eye problems & 3.00 & 1.55 & 2.38 & 1.20 & $8.61^{* *}$ \\
\hline 29 & Hearing problems & 2.68 & 1.15 & 226 & 1.15 & $7.36^{* *}$ \\
\hline 30 & Dental problems & 3.08 & 1.52 & 2.42 & 1.13 & 8.76 \\
\hline 31 & Frequently getting illness & 2.80 & 1.52 & 2.11 & 1.07 & $9.25^{* *}$ \\
\hline 32 & Sleeping problems & 3.44 & 1.41 & 3.96 & 0.44 & $3.36^{* *}$ \\
\hline 33 & Regular vaccination & 3.48 & 1.35 & 4.00 & 0.28 & $2.64^{* *}$ \\
\hline 34 & Others are help me, when I was sick & 2.64 & 1.15 & 226 & 1.15 & $3.54^{* *}$ \\
\hline 35 & Skin problems & 3.04 & 1.39 & 2.80 & 1.32 & $8.61^{* *}$ \\
\hline 36 & No other problems & 4.36 & 0.81 & 3.80 & 0.40 & $8.08^{* *}$ \\
\hline 37 & Frequently I share my feeling with others & 4.40 & 0.64 & 3.96 & 0.34 & $5.53^{* *}$ \\
\hline 38 & Others are giving advises to me & 4.52 & 0.65 & 3.92 & 0,48 & $4.28^{*}$ \\
\hline 39 & When I disappointed others gave support to me & 4.44 & 0.65 & 3.92 & 0.48 & $2.96^{* *}$ \\
\hline 40 & I care about others problems & 4.44 & 1.04 & 3.5 & 0.94 & $3.35^{* *}$ \\
\hline 41 & I am safe here & 4.64 & 0.7 & 4.0 & 0.56 & $5.53^{* *}$ \\
\hline 42 & No violence and discrimination & 4.64 & 0.86 & 4.03 & 0.87 & $6.30^{* *}$ \\
\hline 43 & I take role model from peer group & 4.56 & 1.08 & 3.88 & 0.43 & $2.58^{\circ}$ \\
\hline 44 & I share my thoughts and feelings with peers & 4.40 & 1.15 & 3.88 & 0.51 & $5.24^{* *}$ \\
\hline 45 & I frequently help to our peer group & 4.52 & 1.04 & 3.80 & 0.63 & $3.36^{* *}$ \\
\hline 46 & Our peer group help to me & 4.72 & 0.54 & 3.92 & 0.62 & $2.21^{* *}$ \\
\hline 47 & I mingle with my peer group & 4.36 & 0.56 & 4.00 & 0.56 & $2.58^{\circ}$ \\
\hline 48 & I take many advises from peer group & 4.12 & 1.33 & 4.03 & 0.52 & $2.77^{* *}$ \\
\hline 49 & We have religious activities & 2.76 & 1.47 & 2.00 & 1.26 & $9.58^{* *}$ \\
\hline 50 & We pray to God & 5.00 & 0.00 & 2.69 & 0.97 & $4.79^{* *}$ \\
\hline 51 & Our organization giving discipline with morals & 4.88 & 0.60 & 3.96 & 0.44 & $2.98^{* *}$ \\
\hline 52 & I believe morals are important in life & 4.96 & 0.20 & 3.92 & 0.62 & $2.88^{* *}$ \\
\hline 53 & I like to obey teachers and elders & 4.84 & 0.62 & 4.00 & 0.48 & $2.25^{*}$ \\
\hline 53 & I obey to law and order & 4.88 & 0.43 & 4.00 & 0.63 & $5.71^{* *}$ \\
\hline 54 & I like to follow rules and regulations & 4.68 & 0.67 & 4.15 & 0.67 & $2.84^{* *}$ \\
\hline
\end{tabular}

"p<,05," $p<.01$ 
Development of Organizational Care and Support Inventory for Sheltered Street Children

TABLE-2

ROATATED FACTOR LOADINGS OF THE PERCEIVING ORGANIZATIONAL CARE AND SUPPORT ITEMS

\begin{tabular}{|c|c|c|c|c|c|c|c|c|}
\hline S.NO & Items & $\begin{array}{c}\text { Factor- } \\
\quad\end{array}$ & Factor-II & Factor-III & Factor-IV & Factor-V & Factor-VI & Factor-VII \\
\hline 1 & Adequate place for sleep & 0.60 & 0.25 & 0.07 & 0.26 & 0.05 & 0.12 & 0.13 \\
\hline 2 & Individual bedding & 0.57 & 0.21 & 0.07 & 0.09 & 0.05 & 0.16 & 0.06 \\
\hline 3 & Enough food & 0.70 & 0.15 & 0.06 & 0.22 & 0.08 & 0.12 & 0.16 \\
\hline 4 & Adequate water to drink & 0.70 & 0.00 & 0.04 & 0.12 & 0.18 & 0.13 & 0.04 \\
\hline 5 & Sufficient clothes & 0.75 & 0.01 & 0.03 & 0.16 & 0.16 & 0.03 & 0.01 \\
\hline 6 & Adequate basic facilities & 0.71 & 0.13 & 0.08 & 0.26 & 0.14 & 0.07 & 0.10 \\
\hline 7 & Surroundings are neat and clean & 0.68 & 0.15 & 0.05 & 0.06 & 0.10 & 0.09 & 0.18 \\
\hline 8 & Playing games & 0.44 & 0.32 & 0.03 & 0.36 & 0.07 & 0.11 & 0.19 \\
\hline 9 & Adequate play ground & 0.52 & 0.43 & 0.03 & 0.23 & 0.12 & 0.00 & 0.10 \\
\hline 10 & Compulsory primary education & 0.07 & 0.56 & 0.00 & 0.14 & 0.09 & 0.21 & 0.14 \\
\hline 11 & Sufficient stationary & 0.30 & 0.64 & 0.06 & 0.12 & 0.05 & 0.24 & 0.25 \\
\hline 12 & | like school & 0.13 & 0.68 & 0.00 & 0.08 & 0.08 & 0.02 & 0.01 \\
\hline 13 & Sharing doubts with others & 0.35 & 0.46 & 0.03 & 0.02 & 0.19 & 0.22 & 0.23 \\
\hline 14 & Teachers clarifies our doubts & 0.16 & 0.64 & 0.00 & 0.03 & 0.21 & 0.24 & 0.05 \\
\hline 15 & Teachers concerned about academics & 0.20 & 0.62 & 0.00 & 0.07 & 0.20 & 0.30 & 0.19 \\
\hline 16 & I like studies & 0.11 & 0.64 & 0.07 & 0.17 & 0.14 & 0.22 & 0.03 \\
\hline 17 & Training in computers/ mechanical & 0.02 & 0.44 & 0.10 & 0.16 & 0.03 & 0.39 & 0.04 \\
\hline 18 & Training in vocational courses & 0.01 & 0.21 & 0.05 & 0.14 & 0.06 & 0.46 & 0.22 \\
\hline 19 & Library facility & 0.09 & 0.27 & 0.06 & 0.04 & 0.02 & 0.60 & 0.04 \\
\hline 20 & $\begin{array}{c}\text { Providing Job opportunities after } \\
\text { education }\end{array}$ & 0.15 & 0.20 & 0.02 & 0.00 & 0.31 & 0.51 & 0.15 \\
\hline 21 & Education with morals & 0.18 & 0.16 & 0.02 & 0.06 & 0.27 & 0.67 & 0.04 \\
\hline 22 & Guidance and counseling facility & 0.16 & 0.28 & 0.01 & 0.14 & 0.10 & 0.65 & 0.02 \\
\hline 23 & Emergency medical services & 0.30 & 0.30 & 0.11 & 0.51 & 0.11 & 0.11 & 0.14 \\
\hline 24 & Regular health check ups & 0.26 & 0.23 & 0.12 & 0.53 & 0.08 & 0.10 & 0.20 \\
\hline 25 & First aid facility & 0.21 & 0.31 & 0.11 & 0.52 & 0.18 & 0.03 & 0.24 \\
\hline 26 & Eye problems & 0.05 & 0.02 & 0.78 & 0.05 & 0.08 & 0.12 & 0.04 \\
\hline 27 & Hearing problems & 0.00 & 0.04 & 0.83 & 0.01 & 0.01 & 0.08 & 0.03 \\
\hline 28 & Dental problems & 0.02 & 0.03 & 0.81 & 0.14 & 0.01 & 0.07 & 0.04 \\
\hline 29 & Frequently getting illness & 0.02 & 0.01 & 0.74 & 0.05 & 0.01 & 0.04 & 0.01 \\
\hline 30 & Sleeping problems & 0.02 & 0.02 & 0.77 & 0.03 & 0.04 & 0.05 & 0.15 \\
\hline 31 & Others are help me, when I was sick & 0.03 & 0.04 & 0.00 & 0.18 & 0.03 & 0.05 & 0.56 \\
\hline 32 & Skin problems & 0.13 & 0.03 & 0.69 & 0.05 & 0.00 & 0.02 & 0.02 \\
\hline 33 & No other problems & 0.11 & 0.09 & 0.18 & 0.26 & 0.04 & 0.04 & 0.48 \\
\hline 34 & $\begin{array}{l}\text { Frequently I share my feeling with } \\
\text { others }\end{array}$ & 0.21 & 0.21 & 0.10 & 0.09 & 0.31 & 0.07 & 0.60 \\
\hline 35 & Others are giving advises to me & 0.23 & 0.10 & 0.07 & 0.10 & 0.27 & 0.02 & 0.66 \\
\hline 36 & $\begin{array}{l}\text { When I disappointed others gave } \\
\text { support to me }\end{array}$ & 0.22 & 0.17 & 0.04 & 0.04 & 0.24 & 0.06 & 0.59 \\
\hline 37 & I care about others problems & 0.16 & 0.12 & 0.11 & 0.02 & 0.12 & 0.16 & 0.57 \\
\hline 38 & No violence and discrimination & 0.14 & 0.14 & 0.06 & 0.00 & 0.03 & 0.29 & 0.45 \\
\hline 39 & I take role model from peer group & 0.18 & 0.09 & 0.01 & 0.02 & 0.56 & 0.22 & 0.07 \\
\hline 40 & $\begin{array}{l}\text { I share my thoughts and feelings with } \\
\text { peers }\end{array}$ & 0.10 & 0.05 & 0.02 & 0.09 & 0.68 & 0.15 & 0.05 \\
\hline 41 & I frequently help to our peer group & 0.18 & 0.18 & 0.10 & 0.15 & 0.62 & 0.29 & 0.12 \\
\hline 42 & Our peer group help to me & 0.12 & 0.18 & 0.04 & 0.32 & 0.52 & 0.11 & 0.23 \\
\hline 43 & I mingle with my peer group & 0.10 & 0.09 & 0.05 & 0.24 & 0.66 & 0.09 & 0.16 \\
\hline 44 & I take many advises from peer group & 0.04 & 0.10 & 0.00 & 0.10 & 0.63 & 0.10 & 0.18 \\
\hline 45 & We have religious activities & 0.09 & 0.00 & 0.06 & 0.60 & 0.09 & 0.01 & 0.04 \\
\hline 46 & We pray to God & 0.15 & 0.04 & 0.04 & 0.67 & 0.01 & 0.01 & 0.01 \\
\hline 47 & $\begin{array}{c}\text { Our organization giving discipline with } \\
\text { morals }\end{array}$ & 0.24 & 0.00 & 0.05 & 0.58 & 0.26 & 0.12 & 0.11 \\
\hline 48 & I believe morals are important in life & 0.34 & 0.07 & 0.01 & 0.46 & 0.29 & 0.17 & 0.14 \\
\hline 49 & I like to obey teachers and elders & 0.32 & 0.23 & 0.08 & 0.44 & 0.30 & 0.27 & 0.04 \\
\hline
\end{tabular}




\section{PHYSICAL FACILITIES}

The street children evaluate their organizational care and support with basic needs, basic facilities, hygienic environment and play-off.

Factor - II includes seven items: compulsory education, educational possessions, Attitude toward school, teachers concerning academics of children, clarifying doubts with teacher and peer group and interest in studies. The highest factor

loading of 0.68 is for attitude towards school and lowest of 0.46 is for clarifying doubts with peer group. The factor has been named as SCHOOLING. The street children assess their organizational support, school, education, teaching, educational belongings and also interest in studies.

Factor -III has six items: visual problems, hearing problems, dental problems, sleeping problems, skin diseases and general illness like cough, cold fever etc. The highest factor loading of 0.83 is for hearing problems and lowest of 0.69 is for skin diseases. It was named as HEALTH PROBLEMS. It is mainly for health problems of street children.

Factor - IV contains eight items. These are medical services, religious activities, and inculcating morals in organization. The highest factor loading of 0.67 is for praying god and lowest of 0.44 for respect to teachers and elders. The factor named as ORGANIZATIONAL PROCEDURES. It includes medical services, inculcating morals and religious activities are performing in organization.

Factor $-\mathrm{V}$ has six items. These are sharing feelings and thoughts, helping,mingling, and taking advices and take role model with peer group. The highest factor loading of 0.68 is for sharing feelings and thoughts and lowest of 0.56 is for take a role model in peer group. It is named as PEER GROUP SUPPORT. The street children asses their peer group support in the organization.

Factor - VI includes five items. These are vocational training, library, and employment after education, education with morals and values, and guidance and counseling center. The highest factor loading of 0.65 is for guidance and counseling center, lowest for 0.46 is for providing vocational training. It is named ORGANIZATIONAL FACILITIES. The street children asses their organizational services in the shelters.

Factor - VII it has seven items, which are like to take advises and suggestions, sharing feelings, encouraging and bother about with friends, teachers and warden and also violence and discrimination in the organization. The highest factor loading of 0.66 is for take advises and suggestions and lowest for 0.45 is violence and discrimination in the organization. This factor named as SOCIAL SUPPORT. The street children evaluate their social support in the organization. 
In order to test the assumption that factor analysis may decrease the problem of multi-co linearity, an inter correlation of the seven factors was performed. The results (table- 3) indicate that though, a few relations are significant, the number of correlations are reduced, the mean correlation being 0.33 , it is felt that the problem of multi-co linearity was reduced to some extent, and hence a multiple regression analysis with these seven factors could be performed.

TABLE - 3

Inter correlation of organizational care and support factors

\begin{tabular}{|c|c|c|c|c|c|c|}
\hline Factors & Factor - II & Factor - III & Factor - IV & Factor - $v$ & Factor - VI & Factor - VII \\
\hline Factor-I & $0.52 * *$ & 0.03 & $0.63^{* *}$ & $0.45 * *$ & $0.37^{*}$ & $0.38^{*}$ \\
\hline Factor-II & & 0.02 & $0.47^{* *}$ & $0.43^{*}$ & $0.56^{* *}$ & $0.38^{*}$ \\
\hline Factor - III & & & 0.10 & 0.02 & 0.05 & 0.05 \\
\hline Factor-IV & & & & $0.53^{* *}$ & $0.41^{*}$ & $0.45^{* *}$ \\
\hline Factor - V & & & & & $0.42^{*}$ & $0.46^{* *}$ \\
\hline Factor - VI & & & & & & $0.37 *$ \\
\hline
\end{tabular}

\section{USE OF THE TOOL}

The investigator envisaged the following uses of the tool developed.

- This tool will help in identifying high or low organizational care and support of sheltered street children.

- Provide reasons for low organizational care and support.

\section{REFERENCES}

Brendtro, L. K, Brokenleg, M. \& Van Bockern, S (1990): Reclaiming youth at risk, Bloomington IN: National Education Service.

Pringle, M. K. (1974). The needs of children. London: Hutchinson.

Scharf, W., Powell, M., \& Thomas, E. (1986): Strollers: Street children of CapeTown. In S. Burman \& P. Reynolds (Eds.), Growing up in a divided society: The context of childhood of South Africa. Johannesburg: Ravan Press. 


\section{Development of Organizational Care and Support Inventory for Sheltered Street Children}

Sekar, Aravindaraj, Arul Roncalli, Kavitha, Manoj \& Sanjeev Kumar. (2008): prepared "MY WORK BOOK" on psychosocial care for children in difficult circumstances, National Institute of Mental health and Neurosciences (NIMHANS) Bangalore.

UNICEF and Arab league (2005): A joint report published on Street children in Palestinian.

Zena Amury \& Aneth Komba (2010): Coping strategies used by street children in the event of illness. Research on poverty Alleviation. Research report 10/1. 